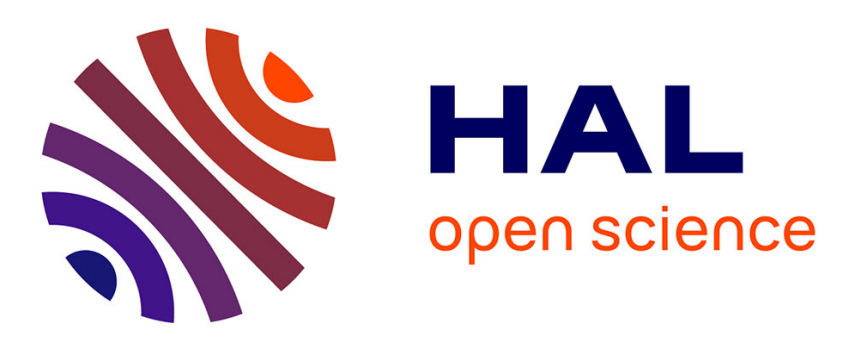

\title{
Improved field margins highly increase slug activity in Switzerland
}

Lisa Eggenschwiler, Bernhard Speiser, Andreas Bosshard, Katja Jacot

\section{To cite this version:}

Lisa Eggenschwiler, Bernhard Speiser, Andreas Bosshard, Katja Jacot. Improved field margins highly increase slug activity in Switzerland. Agronomy for Sustainable Development, 2013, 33 (2), pp.349354. 10.1007/s13593-012-0101-1 . hal-01201346

\section{HAL Id: hal-01201346 https://hal.science/hal-01201346}

Submitted on 17 Sep 2015

HAL is a multi-disciplinary open access archive for the deposit and dissemination of scientific research documents, whether they are published or not. The documents may come from teaching and research institutions in France or abroad, or from public or private research centers.
L'archive ouverte pluridisciplinaire HAL, est destinée au dépôt et à la diffusion de documents scientifiques de niveau recherche, publiés ou non, émanant des établissements d'enseignement et de recherche français ou étrangers, des laboratoires publics ou privés. 


\title{
Improved field margins highly increase slug activity in Switzerland
}

\author{
Lisa Eggenschwiler • Bernhard Speiser • \\ Andreas Bosshard • Katja Jacot
}

Accepted: 21 June 2012 / Published online: 11 October 2012

(C) INRA and Springer-Verlag, France 2012

\begin{abstract}
Most field margins on arable land in Switzerland are narrow and intensively managed. As a consequence, field margins generally harbour few plant and animal species. To enhance biodiversity in arable landscapes, sown species-rich field margins, so-called improved field margins, were introduced in 2008 as a part of the Swiss agri-environment scheme. Here, we tested whether improved field margins increase slug activity density. Slug activity density in and next to improved field margins was compared to slug activity in and next to conventional field margins. Over a period of 3 years, slugs were sampled in three regions in northern Switzerland in late spring using bait stations. Our results show that improved field margins have higher slug activity density, of $+191 \%$, than conventional field margins, independently of the region. The predominant slugs were Arion lusitanicus and Deroceras spp. While A. lusitanicus was generally more abundant in field margins than in fields, with intermediate numbers in
\end{abstract}

K. Jacot $(\bowtie)$

Agroscope Reckenholz-Tänikon Research Station ART,

Reckenholzstrasse 191,

8046 Zurich, Switzerland

e-mail: katja.jacot@art.admin.ch

B. Speiser

Research Institute of Organic Agriculture FiBL,

Ackerstrasse,

5070 Frick, Switzerland

\section{A. Bosshard}

Institute of Environmental Sciences, University of Zurich,

Winterthurerstrasse 190,

8057 Zurich, Switzerland

\section{Eggenschwiler}

Christoph Merian Foundation,

St. Alban-Vorstadt 5, Postfach,

4002 Basel, Switzerland

e-mail: lisa.eggenschwiler@art.admin.ch the adjacent crop margins, Deroceras spp. showed a more even distribution.

Keywords Arion lusitanicus · Deroceras spp. · Pest slug · Agri-environment scheme - Crop protection .

Semi-natural habitat . Ecological infrastructure

\section{Introduction}

Nowadays, field margins along crop borders in Switzerland are usually narrow, mown several times a year and often affected by fertiliser and pesticide drift. Consequently, these conventional field margins generally exhibit low plant and animal diversity (Théato 2002). Seed mixtures and management strategies for species-rich field margins - so-called improved field margins - were developed in order to enhance biodiversity and connect habitats in arable landscapes. Introduced in 2008 as the newest type of ecological compensation area, improved field margins are part of the Swiss agri-environment scheme, and are now subsidised with direct payments. Such field margins are semi-natural, permanent habitats a minimum of $3 \mathrm{~m}$ wide sown with indigenous forbs, grasses and legumes and adjacent to arable fields. They are not fertilised, and weeds are mainly controlled mechanically when necessary. Every second year, half of the field margin is mown lengthways. In contrast to improved field margins, wildflower strips, another type of ecological compensation area on arable land, are not permanent, do not contain sown grasses and are usually not mown during the vegetation period.

Previous studies carried out in experimental improved field margins have shown that they enhance the diversity of many groups of organisms such as plants, butterflies, grasshoppers, ground beetles and spiders (Jacot et al. 2007). Given, however, that alternative farming practices such as set-aside can lead to increased populations of crop pests such as slugs (Griffiths et al. 
1998), it stands to reason that improved field margins could also provide a suitable habitat for slugs.

Mechanical soil cultivation reduces slug populations directly by damaging slugs or egg batches, or indirectly by destroying the vegetation cover or soil macropores serving as refuge habitats for them (Voss et al. 1998). Since the soil of improved field margins is not cultivated after sowing, slugs may find conditions in such margins to be favourable.

Improved field margins usually have a various vegetation structure, which can protect slugs from desiccation. Moreover, such areas are likely to harbour various oviposition sites and different fodder plants. It is unclear whether the vegetation of improved field margins serves as a preferred food source, or whether slugs spread out into the crop to feed. Studies with freshly sown wildflower strips and narrow grassy strips adjacent to oilseed rape showed the highest slug damage to the crops at one metre's distance from the strips, declining with increasing distance from the latter (Frank 1998a, b). In contrast to this result, Hof and Bright (2010) found that the presence of grassy field margins decreased the abundance of gastropods in adjacent arable fields.

To date, no information has been published on the influence of improved field margins on slug activity density. As improved field margins are the newest type of ecological compensation area, for practice it is important to know how they influence slug populations in the margins and the adjacent crops. Improved field margins are wider and managed more extensively than conventional field margins, and may differ from the latter in various aspects such as type and structure of vegetation cover or microclimate (e.g. they usually contain more plant species and dead plant material). Consequently, slug activity density could be increased in improved field margins.

In this study, newly established improved field margins were compared to conventional field margins, the predominant type in Switzerland. The following questions were addressed: (1) Is slug activity density in improved field margins higher than those in conventional field margins? (2) How do the two types of field margins influence slug activity density in the crop? (3) To what extent do sampling year and region affect the abundance of slugs?

\section{Materials and methods}

\subsection{Study region and experimental fields}

Sampling was carried out in three regions in the northern part of Switzerland: Aesch (Basel-Land canton), Oberwil-Lieli (Aargau canton) and the Klettgau (Schaffhausen canton). Although arable farming is common in all three regions, they differ from one another in terms of altitude, climate and soil properties. In Aesch (300-500 ma.s.1.), mean annual precipitation is $849 \mathrm{~mm}$, mean annual temperature $10.7{ }^{\circ} \mathrm{C}$ (mean values for 2002, 2004 and 2005 in Binningen, 7-km distance; MeteoSchweiz (2011)) and most abundant soil types are brown earth and pseudogley. In Klettgau (420 470 ma.s.l.), mean annual precipitation is $1,023 \mathrm{~mm}$, mean annual temperature $9.6{ }^{\circ} \mathrm{C}$ (mean values for 2002, 2004 and 2005 in Hallau, 5-km distance; MeteoSchweiz (2011)) and most abundant soil type is brown earth with high clay and stone content. In Oberwil-Lieli (530-620 ma.s.1.), mean annual precipitation is $1,042 \mathrm{~mm}$, mean annual temperature $9.8{ }^{\circ} \mathrm{C}$ (mean values for 2002, 2004 and 2005 in ZurichReckenholz, 13-km distance; MeteoSchweiz (2011)) and most abundant soil types are sandy loam, gleysol (buntgley) and pseudogley-brown earth.

Slugs were sampled in newly sown improved field margins and conventional field margins. The improved field margins, strips of 3 or $5 \mathrm{~m}$ width along the crop borders, were sown in 2001 for the experiment. Depending on the prevailing site conditions (dry, fresh or moist), the seed mixtures sown contained 26 to 35 indigenous forb, legume and grass species, and during the study period, an average of 19 plant species per $20 \mathrm{~m}^{2}$ were found in the improved field margins. Estimated average moist mass of forbs in the improved field margins was $32 \%$. Once every second year in August, half the area of the improved field margins was mown lengthwise. The conventional field margins were permanent, grass-dominated strips of around 0.5 to $1 \mathrm{~m}$ in width alongside arable crops. Mown twice or three times a year, they harboured few grass, forb and legume species (personal observation; five to ten plant species per $20 \mathrm{~m}^{2}$; 5-20\% of moist mass were forbs).

In each study region, three conventional and three improved field margins were examined. In Oberwil-Lieli, one of the improved field margins was ploughed at the beginning of the final study year owing to weed problems, and crop rotation was resumed. As a replacement, a comparable improved field margin which had been sown in 2003 was included in the experiment. Slugs were collected within the field margin, in the adjacent crop at one metre's distance ('crop margin'), and at 15-m distance from the field margin ('crop'). The fields were approximately 1 ha in size, and the crops were cereal (in 26 cases), grass-clover ley (14), maize (3), wildflower strip (3), sunflower (2), sugar beet (2), pasture (2), potato (1), soybean (1) and broad bean (1). Pasture and wildflower strips were included and used for the analyses because slug activity density here was not substantially different from those found in the arable crops, for which not enough numbers were available.

\subsection{Slug sampling}

Slug activity density was measured once at the beginning of May and once at the end of May/beginning of June in 2002, 
2004 and 2005, respectively. Samplings were done in May and June because these are the months when the fields are usually covered with crops and slug populations are quite large (Grimm 2001). At each time period, the three regions were sampled on three subsequent days using bait stations ('slug trap 007', B. Egger, Abtwil, Switzerland; Fig. 1). Each trap consisted of a plastic pot saucer with a diameter of $15 \mathrm{~cm}$, baited with five slices of cucumber and covered with a plastic lid. A gap was left to allow the slugs to enter the trap. Eight traps were positioned in each habitat, i.e. field margin, crop margin or crop, in a transect $10 \mathrm{~m}$ apart from each other. The traps were placed on the soil surface before dusk and left exposed overnight. Between 6 and 9 a.m. the following morning, the slugs in or on the traps were counted, identified in the field and released again. Since Arion hortensis s.s. and Arion distinctus can only be distinguished on the basis of the internal anatomy of their reproductive systems (Iglesias and Speiser 2001), these slugs were not identified to species level.

\subsection{Statistical analyses}

The slug numbers of the eight traps per transect were summed for the analyses and referred to as slug activity density. Slug data of the two sampling periods per year were pooled because we were interested in the annual effect rather than in individual dates. Slug numbers were logtransformed to meet the assumptions of the performed regressions (normal distribution and homogeneity of residual variance). Data were analysed with linear mixed regression, and inferences on the variables were obtained using likelihood ratio tests. Region, field margin type, habitat and year were fixed factors, while crop type was a random factor. Tukey's post hoc test was used to analyse differences between groups. All statistical tests were performed using

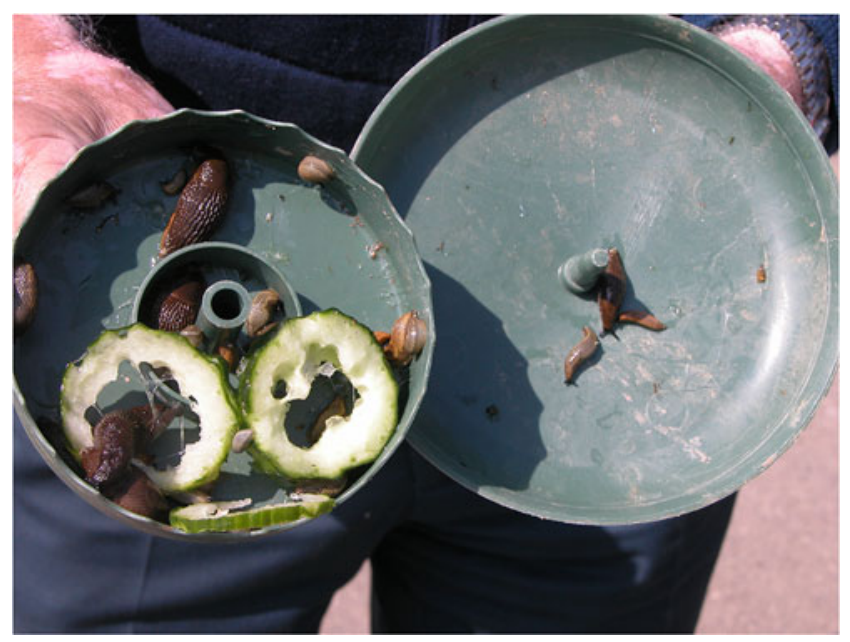

Fig. 1 Slug trap with slugs and cucumber slices (photo: Stephan Bosshart, ART) the statistics software R, version 2.12.1 (R-DevelopmentCore-Team 2010).

\section{Results and discussion}

\subsection{Slug activity density and trapping methods}

A total of 9,076 slugs were sampled over the entire study period, comprising 4,740 specimens of Arion lusitanicus, 4,193 Deroceras spp. and 143 A. distinctus/A. hortensis s.s. No other slug species were sampled. On the whole, most $A$. lusitanicus individuals were found in the improved field margins $(n=1,926)$, and to a lesser extent in the adjacent crop margins $(n=1,127)$, whilst in the conventional field margins, 476 individuals were sampled and in the adjacent crop margins 553. Overall, and irrespective of the adjacent field margin type, the lowest total numbers of A. lusitanicus, i.e. 306 (adjacent to improved field margins) and 352 (adjacent to conventional field margins) individuals, respectively, were counted in the crops. High numbers of Deroceras spp. individuals were recorded in improved field margins $(n=948)$, the adjacent crop margins $(n=825)$ and crops $(n=$ 780 ), but differences between habitats were less pronounced than for A. lusitanicus. Fewer individuals were counted in the conventional field margins $(n=592)$ and adjacent crop margins $(n=493)$ and crops $(n=555)$. The majority of $A$. distinctus/A. hortensis s.s. individuals $(n=109)$ were found in the crops. Because of their low numbers, this group was not further analysed.

Baiting methods are commonly used to trap slugs in different crop and habitat types, but they are biased in favour of certain species. Deroceras reticulatum, a surfacedwelling slug, and A. lusitanicus that is also often found on or near the soil surface, are more likely to be trapped than $A$. hortensis s.s., a species active underground (Hunter 1968). The abundance of $A$. hortensis slugs may therefore have been underestimated. Given that the dominant slug species of our study, D. reticulatum and A. lusitanicus, are now the major pest slugs across wide regions of Europe (South 1992; Grimm and Paill 2001) as well as in Switzerland (Speiser et al. 2001), the trapping method clearly covered the most important species of pest slugs.

\subsection{Effect of field margin type on slug activity density}

Field margin type significantly influenced slug activity density (Table 1). Often, activity density of both $A$. lusitanicus and Deroceras spp. was significantly higher in the improved field margins than in the conventional margins (Figs. 2 and 3 , Table 1). The main reason for this result is probably the less intensive management of improved field margins. A high abundance and variety of forbs may also have 
Table 1 Effects of region, field margin type (improved, conventional), habitat (field margin, crop margin, crop), and year on the total number of slug individuals and on the number of $A$. lusitanicus and Deroceras spp. slug individuals recorded separately (activity density)

Data were log-transformed and analysed with linear mixed regression, and inference on variables is based on likelihood ratio tests

\begin{tabular}{|c|c|c|c|c|c|c|c|}
\hline & \multirow[t]{2}{*}{ Df effect } & \multicolumn{2}{|c|}{ Both slugs } & \multicolumn{2}{|c|}{ Arion lusitanicus } & \multicolumn{2}{|c|}{ Deroceras spp. } \\
\hline & & $\mathrm{Chi}^{2}$ & $P\left(\geq \mathrm{Chi}^{2}\right)$ & $\mathrm{Chi}^{2}$ & $P\left(\geq \mathrm{Chi}^{2}\right)$ & $\mathrm{Chi}^{2}$ & $P\left(\geq \mathrm{Chi}^{2}\right)$ \\
\hline Region & 2 & 17.55 & $<0.001$ & 14.60 & $<0.001$ & 11.73 & 0.003 \\
\hline Field margin type & 1 & 13.25 & $<0.001$ & 5.06 & 0.024 & 12.66 & $<0.001$ \\
\hline Habitat & 2 & 13.89 & $<0.001$ & 13.46 & 0.001 & 6.89 & 0.032 \\
\hline Year & 2 & 60.47 & $<0.001$ & 23.93 & $<0.001$ & 43.52 & $<0.001$ \\
\hline Region $\times$ field margin type & 2 & 0.15 & 0.941 & 3.55 & 0.169 & 0.76 & 0.683 \\
\hline Region $\times$ habitat & 4 & 6.82 & 0.146 & 11.16 & 0.025 & 7.90 & 0.095 \\
\hline Region $\times$ year & 4 & 54.56 & $<0.001$ & 36.81 & $<0.001$ & 64.47 & $<0.001$ \\
\hline Field margin type $\times$ habitat & 2 & 2.55 & 0.280 & 5.54 & 0.063 & 0.27 & 0.875 \\
\hline Field margin type $\times$ year & 2 & 13.62 & 0.001 & 4.57 & 0.102 & 11.24 & 0.004 \\
\hline Habitat $\times$ year & 4 & 5.64 & 0.228 & 3.16 & 0.531 & 5.09 & 0.278 \\
\hline
\end{tabular}

contributed to the creation of a more favourable slug habitat (Cook et al. 1996; Briner and Frank 1998).

Slugs have many natural enemies, for example several species of nematodes, carabids, staphylinids, glow worms, protozoa, birds and mammals (e.g. hedgehogs) (Barker 2004). Improved field margins and wildflower strips promote slug predators such as carabids and staphylinids (Pfiffner and Luka 2000), but these two Coleoptera families also benefit from simple grassy strips (beetle banks) (MacLeod et al. 2004). However, it is still unclear for many slug predators to

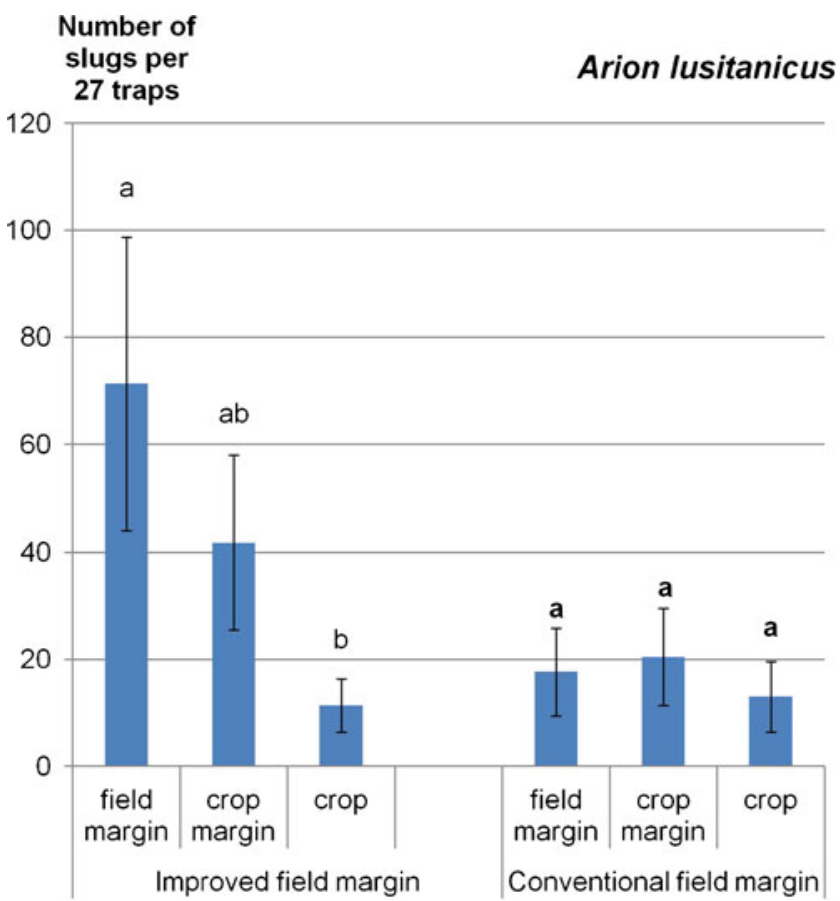

Fig. 2 Numbers (activity density) of A. lusitanicus in the three habitat types of the two field-margin-type treatments (means $\pm \mathrm{SE}, n=3$; data summarised for all years and regions). Slugs were counted in the field margins, adjacent crop margins and crops. Different letters above bars indicate significant differences between habitats within the same field margin type which extent their populations are influenced by the habitat type and if the predation pressure on slugs is different in improved field margins compared to conventional ones.

\subsection{Effect of habitat on slug numbers}

Irrespective of the field margin type, activity density of $A$. lusitanicus was different in the three habitats (field margins, crop margins, crops; Table 1), in particular being higher in the field margins than in the crops (Table 2, Fig. 2). A study

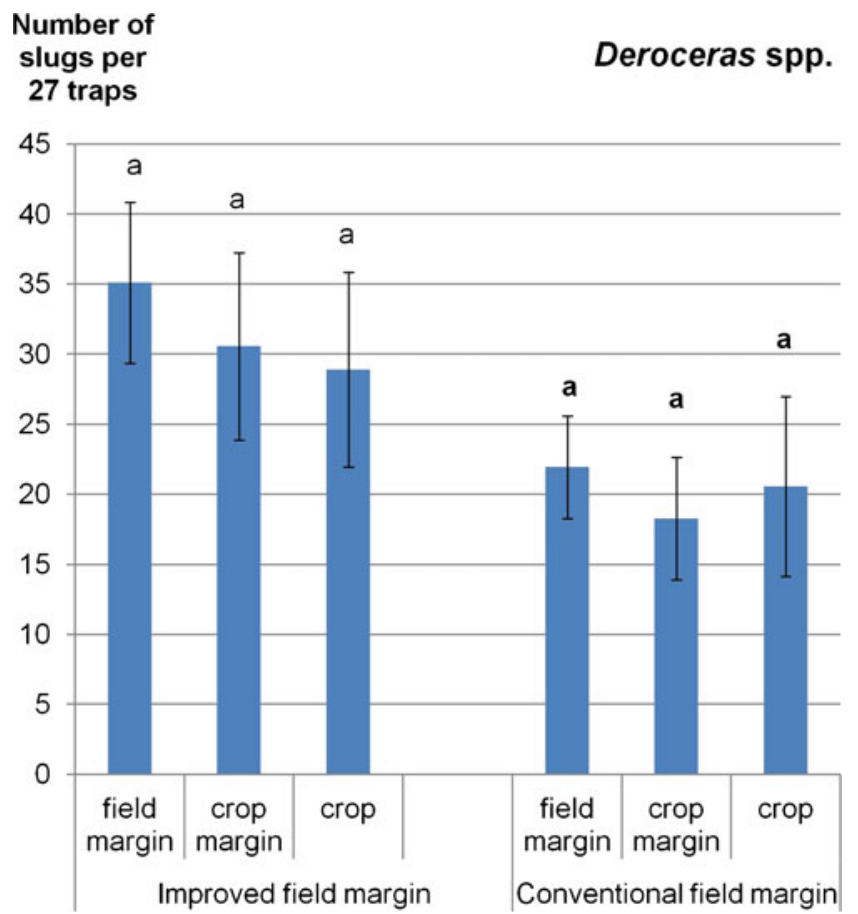

Fig. 3 Numbers (activity density) of Deroceras spp. in the three habitat types of the two field-margin-type treatments (means $\pm \mathrm{SE}, n=$ 3 ; data summarised for all years and regions). Slugs were counted in the field margins, adjacent crop margins and crops. Different letters above bars indicate significant differences between habitats within the same field margin type 
Table 2 Multiple comparisons of means of main effects using Tukey's post hoc test

\begin{tabular}{lrcc}
\hline & All slugs & Arion lusitanicus & Deroceras spp. \\
\hline $2002-2004$ & $<0.001$ & $<0.001$ & $<0.001$ \\
$2002-2005$ & 0.028 & 0.564 & 0.173 \\
$2004-2005$ & $<0.001$ & $<0.001$ & $<0.001$ \\
Aesch-Klettgau & $<0.001$ & $<0.001$ & 0.003 \\
Aesch-Oberwil & 0.627 & 0.809 & 0.999 \\
Klettgau-Oberwil & $<0.001$ & 0.002 & 0.002 \\
Field margin-crop & 0.028 & 0.352 & 0.096 \\
$\quad$ margin & & & \\
Field margin-crop & $<0.001$ & $<0.001$ & 0.042 \\
Crop margin-crop & 0.504 & 0.048 & 0.936 \\
\hline
\end{tabular}

Shown are adjusted $p$ values using the single-step method for all slug individuals and for A. lusitanicus and Deroceras spp. separately

by Zweifel (1998) showed A. lusitanicus to be more numerous in crops adjacent to wildflower strips; sometimes this species was abundant up to $12 \mathrm{~m}$ into the crop. Zweifel (1998) concluded that A. lusitanicus numbers were encouraged by wildflower strips. Friedli and Frank (1998) and Calame (2000) found A. lusitanicus in higher numbers in wildflower strips than in the crops, and Speiser and Niederhauser (1997) counted more A. lusitanicus individuals in extensively managed grassland than in crops, which accords with our findings. In the adult stage, $A$. lusitanicus is a very large slug which can hardly penetrate into the soil, and is therefore reliant on dense vegetation for shelter. This favours the establishment of populations in field margins rather than in crop fields.

In this study, the distribution of Deroceras spp. was relatively even, with only a slightly significant difference between field margins and crops (Table 2, Fig. 3). Similarly to our results, in experiments by Frank (1998b) and Friedli and Frank (1998), D. reticulatum was evenly distributed over arable fields adjacent to sown wildflower strips. Zweifel (1998) never found higher numbers of $D$. reticulatum in sown wildflower strips than in the adjacent wheat plots. Nevertheless, it was observed that numbers of this species increased with distance from the edge of the wildflower strips when the crop was well developed and thus afforded cover (Zweifel 1998). D. reticulatum can penetrate well into the soil in the daytime, where it is protected from drying out, and where it also survives soil cultivation. This favours the establishment of permanent populations in crop fields.

Crop type as random factor had a significant effect on slug activity density (data not shown). This means that it is important which crop type is situated adjacent to the field margins. Reasons for this might be that crops differ regarding their attractiveness as food and as habitat for slugs.

\subsection{Effect of year and region on slug activity density}

Slug activity density differed considerably between years both for A. lusitanicus and Deroceras spp. (Table 1). The year 2004 was significantly different from the other 2 years (Table 2), with remarkably low slug activity density (data not shown). Whereas climate data were quite similar and not exceptional in 2004 and 2005, the summer of 2003 was characterised by heat and drought in Europe (Ciais et al. 2005). In Switzerland, it was the warmest and driest summer since the beginning of systematic climate measurements in 1864 (Bader 2004). The low slug activity density in 2004 may have been the result of this climatic phenomenon - the longer the period of dry weather, the greater the reduction in subsequent slug population numbers (Willis et al. 2003).

Slug activity density did not increase with the age of the field margins. The significant field margin type $\times$ year interaction (Table 1) also indicates that slug activity density in improved field margins (particularly those of Deroceras spp.) was not higher in all years. Independently of the year, habitat type had the same effect on the slugs (Table 1). Region as well as year had a highly significant effect on slug activity density (Table 1), with the Klettgau region differing significantly from the other two regions (Table 2). It was not possible to investigate the reasons for these differences in this project, but it is worthwhile to note that Klettgau differs from the other two regions in terms of climate and soil properties. Furthermore, during one of the two samplings in Klettgau in 2005, a very cold wind was blowing (personal observation).

Further, there was an interaction of year and region (Table 1): in the Klettgau region in particular, few slugs were found in both 2004 and 2005 (data not shown). Depending on the region, A. lusitanicus showed a slightly different distribution within the three habitats (Table 1); despite this, no region $\times$ field-margin-type interaction was found (Table 1). It therefore appears that improved field margins served to increase slug activity density independently of the region.

\section{Conclusions}

Slug activity density was increased by the establishment of improved field margins in our study. This means that crops grown near improved field margins suffer a higher risk of slug damage. Where possible, farmers should refrain from growing susceptible crops such as oilseed rape or sugar beet adjacent to an improved field margin. If necessary, a strip treatment with molluscicide pellets may reduce slug damage (Friedli and Frank 1998). 
Acknowledgments Our thanks go to all those who helped with the field work, especially S. Bosshart, X. Junge, H. Conradin and V. Bosshart. We are grateful to all the farmers who allowed us to perform the samplings in their fields. M. Suter and two members of ETH Zurich's statistical seminar provided useful help with data analyses. We would also like to thank F. Herzog for his valuable comments on an earlier version of the manuscript.

\section{References}

Bader S (2004) Die extreme Sommerhitze im aussergewöhnlichen Witterungsjahr 2003. Arbeitsbericht 200, MeteoSchweiz. http:// www.bafu.admin.ch/klima/00509/00514/index.html. Accessed 14 Sept 2011

Barker GM (2004) Natural enemies of terrestrial molluscs. CABI Publishing, Biddles Ltd, King's Lynn

Briner T, Frank T (1998) The palatability of 78 wildflower strip plants to the slug Arion lusitanicus. Ann Appl Biol 133:123-133. doi:10.1111/j.1744-7348.1998.tb05808.x

Calame F (2000) Dynamique de populations de limaces à la périphérie et à l'intérieur d'une parcelle cultivée. Rev Suisse Agric 32:11-13

Ciais P, Reichstein M, Viovy N, Granier A, Ogée J, Allard V, Aubinet M, Buchmann N, Bernhofer CC, Chevallier F, De Noblet N, Friend AD, Friedlingstein P, Grünwald T, Heinesch B, Keronen P, Knohl A, Krinner G, Loustau D, Manca G, Matteucci G, Miglietta F, Ourcival JM, Papale D, Pilegaard K, Rambal S, Seufert G, Soussana JF, Sanz MJ, Schulze ED, Vesala T, Valentini R (2005) Europe-wide reduction in primary productivity caused by the heat and drought in 2003. Nature 437:529-533. doi:10.1038/nature03972

Cook RT, Bailey SER, McCrohan CR (1996) Slug preferences for winter wheat cultivars and common agricultural weeds. J Appl Ecol 33:866-872. doi:10.2307/2404957

Frank T (1998a) Slug damage and numbers of slugs in oilseed rape bordering on grass strips. J Molluscan Stud 64:461-466. doi:10.1093/mollus/64.4.461

Frank T (1998b) Slug damage and numbers of the slug pests, Arion lusitanicus and Deroceras reticulatum, in oilseed rape grown beside sown wildflower strips. Agric Ecosyst Environ 67:67-78. doi:10.1016/S0167-8809(97)00108-4

Friedli J, Frank T (1998) Reduced applications of metaldehyde pellets for reliable control of the slug pests Arion lusitanicus and Deroceras reticulatum in oilseed rape adjacent to sown wildflower strips. J Appl Ecol 35:504-513. doi:10.1046/j.13652664.1998.3540504.x

Griffiths J, Phillips DS, Compton SG, Wright C, Incoll LD (1998) Responses of slug numbers and slug damage to crops in a silvoarable agroforestry landscape. J Appl Ecol 35:252-260
Grimm B (2001) Life cycle and population density of the pest slug Arion lusitanicus Mabille (Mollusca: Pulmonata) on grassland. Malacologia 43:25-32

Grimm B, Paill W (2001) Spatial distribution and home-range of the pest slug Arion lusitanicus (Mollusca: Pulmonata). Acta Oecol Int J Ecol 22:219-227. doi:10.1016/S1146-609X(01)01115-8

Hof AR, Bright PW (2010) The impact of grassy field margins on macro-invertebrate abundance in adjacent arable fields. Agric Ecosyst Environ 139:2805-283. doi:10.1016/ j.agee.2010.08.01

Hunter PJ (1968) Studies on slugs of arable ground: I. Sampling methods. Malacologia 6:369-377

Iglesias J, Speiser B (2001) Distribution of Arion hortensis s.s. and Arion distinctus in Northern Switzerland. J Molluscan Stud 67:209-214. doi:10.1093/mollus/67.2.209

Jacot K, Eggenschwiler L, Junge X, Luka H, Bosshard A (2007) Improved field margins for a higher biodiversity in agricultural landscapes. Asp Appl Biol 81:277-283

MacLeod A, Wratten SD, Sotherton NW, Thomas MB (2004) 'Beetle banks' as refuges for beneficial arthropods in farmland: long-term changes in predator communities and habitat. Agric For Entomol 6:147-154. doi:10.1111/j.1461-9563.2004.00215.x

MeteoSchweiz (2011) Climate data. https://gate.meteoswiss.ch/idaweb. Accessed 4 Jul 2011

Pfiffner L, Luka H (2000) Overwintering of arthropods in soils of arable fields and adjacent semi-natural habitats. Agric Ecosyst Environ 78:215-222. doi:10.1016/S0167-8809(99)00130-9

R-Development-Core-Team (2010) R: A language and environment for statistical computing. R Foundation for Statistical Computing, Vienna

South A (1992) Terrestrial slugs. Biology, ecology, control. Chapman and Hall, London

Speiser B, Niederhauser D (1997) Fördern extensive Wieslandstreifen Schneckenschäden? Agrarforschung 4:179-180

Speiser B, Glen D, Piggott S, Ester A, Davies K, Castillejo J, Coupland J (2001) Slug damage and control of slugs in horticultural crops. FiBL, Frick, Brochure

Théato C (2002) Field margins as ecological compensation areas? Bull Geobot Inst ETH 68:109-110

Voss MC, Ulber B, Hoppe HH (1998) Impact of reduced and zero tillage on activity and abundance of slugs in winter oilseed rape. $Z$ Pflanzenkrankh Pflanzenschutz 105:632-640

Willis JC, Bohan DA, Choi Y, Semenov M, Brown VK, Gussin E (2003) Comparison of slug population dynamics at five sites in the UK. In: Dussart GBJ (ed) Slugs and snails-agricultural, veterinary and environmental perspectives. Page Bros, Norwich, pp 171-176

Zweifel R (1998) Effects of sown wildflower strips on spatial and temporal dynamics of different slug species in reduced tillage winter wheat. Master Thesis, Geobotanical Institute ETH, Zurich 